\title{
Assessment of Geo-Tourism Structure in Bojnoord City Sustainable Tourism Development
}

\author{
By Pegah Kharazian ${ }^{1}$ \\ University instructor
}

\begin{abstract}
Nowadays, issues such as population growth, gradual reduction of natural resources, increasing pollution, unbalanced distribution in resources, the crisis of ecological conservation, urbanization growth and increasing human awareness are as a result of social changes in human life. Even changes in the attitude of people toward the trip phenomenon lead to several changes in this industry. The concept of ecotourism, geo-tourism, geo-park and sustainable tourism represent the evolution of ideas, including new solutions that will meet the modern world's needs with valued targets in its plan. The emphasis of this article is on morphological characteristics in line with sustainable development goals and ecological resources protection of the region to attract certain tourists through the identification and introducing the potential attraction of the area. Analytical and experimental research methods are based on statistical data, quantitative analysis methods and data collection methods in library and field methods. This case study (Bojnoord city) presents comprehensive image about geomorphological attractions of Bojnoord city. The results indicated that through the internal and external processes of land phenomena, beautiful landscapes such as anticlines, synclines, straits and erosional forms, springs, waterfalls, peaks and valleys with special and unique effects can attract tourists in different ages and educational levels in different seasons of the year.
\end{abstract}

Keywords: Geo-tourism, Ecotourism, Geo-parks, Sustainable tourism, Bojnoord city

\section{Introduction}

Since sustainable development as the main goal of planners has always been interested to decision makers, rural development is not possible without local resident involving in long-term benefits of development. (Drum \& Allen, 2009)

Natural resources protection, living condition improvement in local communities, local cooperating in developing plans and assessing the areas capacities for creating new opportunities are some attempts have been discussed in sustainable development goals.

Many villages of Bojnoord county are located in valleys where is impossible to be agriculturally developed due to land limitation, thus developing the future of these rural areas and focusing on its tourism potential are some useful approaches in sustainable development.

Soil erosion happens as a result of severe grasslands destruction, but solving this problem could be possible by emphasis on tourism and creating secure jobs in rural areas, thus geological and morphological studies of events and area phenomena and assessing the ability of area is vital to attract tourists and create new opportunities for local residents.

According to the following items, it seems that Bojnoord County with several appropriate geomorphological potentials could reach the development goals through proper planning:

1. Bojnoord County locating on pilgrim route of the eighth Imam of Shia (AS) and serve the pilgrims and tourists' needs during their route is an opportunity to attract more pilgrims.

2. The unique feature of Bojnoord County weather as a mountain city where is linking the 
northern cities of Iran to Mashhad city has provided the ideal tourist attraction location.

3. Increasing the population growth, urbanization process and the need for spending leisure time in nature show the necessity of planning.

4. The problems of geological and ecological resources conservation in the area are some concerns of planners and decision-makers.

5. Some features of Bojnoord County as the center location in the province, such as having more tourist facilities and services rather than other cities and proximity to cities around by uniform distance provide the possibility to benefit from the power of geo-tourists potentials of these areas. 6. Some new solutions, such as geo-tourism, geo-park, health roads and green roads can lead to attract more attention to the morphological potentials of the region spontaneously.

Thus, the most important question is about charming attraction of Bojnoord County in terms of geo-tourism and ecotourism. In this regard, it is assumed that Bojnoord has the potential of geotourism and ecotourism development.

\section{Geo-tourism Meanings and Functions}

"Geo-tourism is an informed and responsibly tourism in nature to know the geological phenomena and processes and learning its formation and evolution." (Amri Kazemi, 2009)

In another definition, geo-tourism is the science of studying and applying the outside processes in order to develop tourism. This process leads to form different shapes of land with panoramic landscapes that will change in different biological and climatic conditions of each area. (Shayan, 2006)

Geo-tourism is subset of sustainable tourism and its purpose is to protect the tourism resources in the meaning of guiding tourists to meet the present needs without compromising the ability of future generations to meet their own needs. (Rahmani, 2007)

Global Geo-parks Network (GGN), which was formed in 2004 with 17 Geo-parks in Europe and 8 Geo-parks in China, now has 63 members from 19 countries of the world. Qeshm Geo-park is the only Geo-park of Iran and the Middle East in this network. (Amri Kazemi, 2009)

\section{Location and Geographical Boundaries of Bojnoord County}

Bojnoord county is located in central part of Bojnoord city in according to the following coordinates: from $37^{\circ} 13^{\prime}$ to $38^{\circ} 17$ in North latitude and from $56^{\circ} 19^{\prime}$ to $57^{\circ} 43^{\prime}$ in East longitude. The total area of Bojnoord County is about 6563 square kilometers, equivalent to $23 \%$ of the total area of the province. Bojnoord city is located in the center of North Khorasan province at a distance of $250 \mathrm{~km}$ from North West of Mashhad city. The city has limited to cities and countries around, namely: Turkmenistan in North, North East and North West, Maneh and Samalqan counties in West, Jajarm County in South West, Esfarayen County in south, Shirvan County in South East and East of the city. (Villages encyclopedia, 2005) 


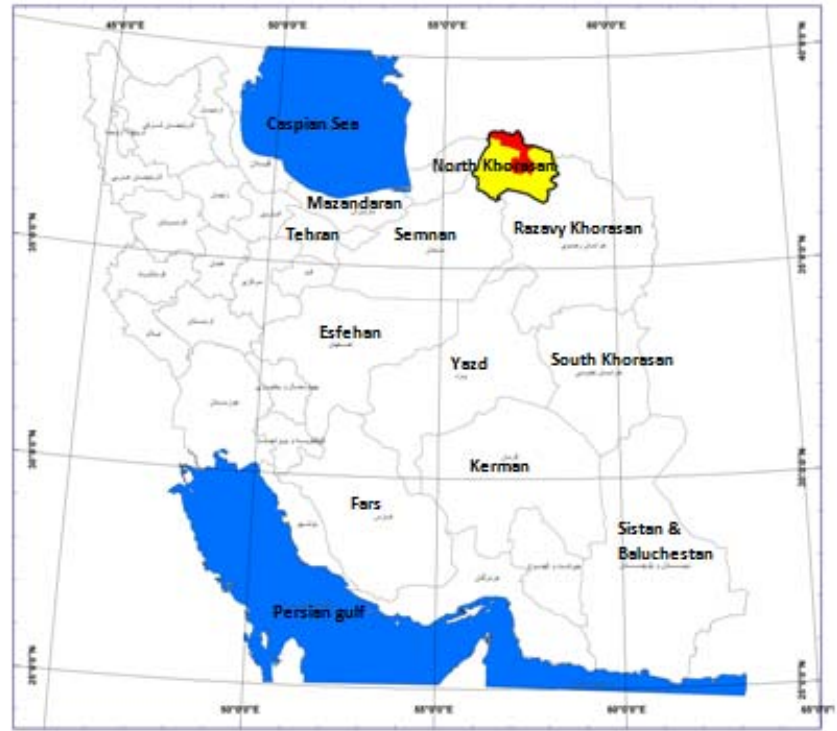

Figure 1. Bojnoord county position in North Khorasan Province

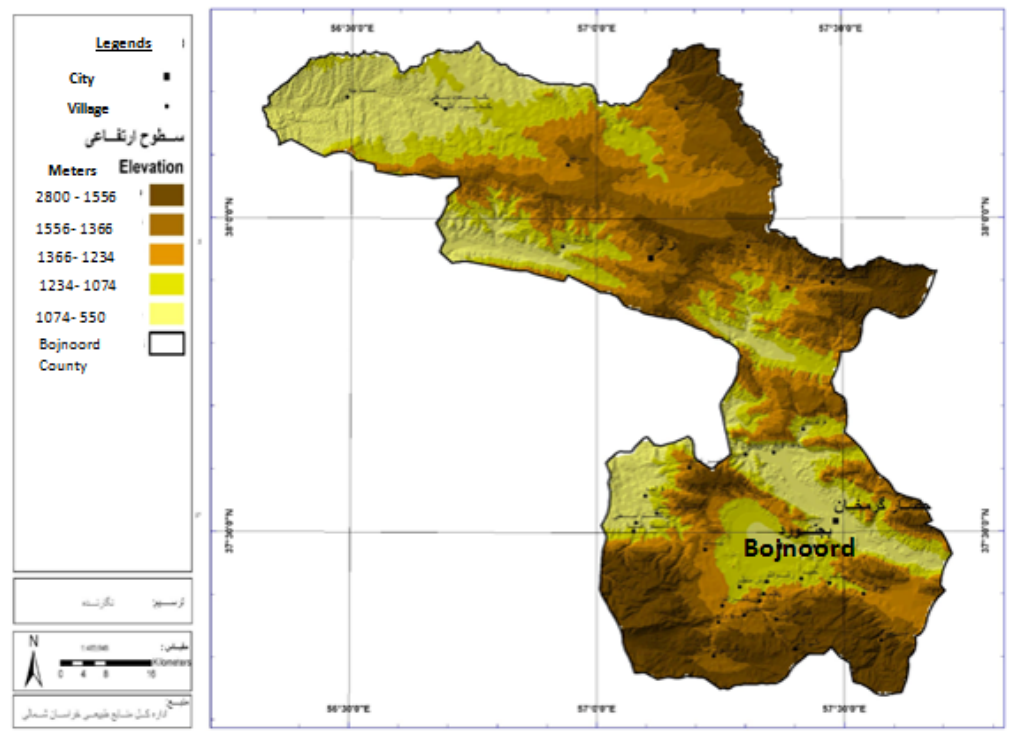

Figure 2. Height levels of Bojnoord County

\section{History and Geological Features}

The most completed Jurassic formations of Iran can be seen in the Kopet Dagh Mountains. The area appeared in the middle Triassic and probably as a result of the former Cimmerian orogeny to become independent as a sedimentary construction zone in Jurassic. (Darvishzadeh, 2003)

The sea sediments accumulated discontinuously on top of the former sediments in the south parts of Kopet dagh and Binalud in early marine Jurassic. Similar Jurassic sediments in both areas 
indicate that there was a similar sedimentary structure in both sedimentary basins at the same time. Thus, the connection between central Iran and Turan plates happened after Triassic and before Jurassic which still continued until early Cretaceous. But then the southern part (Binalud) came out of the water slowly and accumulated on top of older rocks where the outcrops of these areas cannot be seen.

The northern part (Kopet Dagh) still remained under the water with fluctuations in depth, and strip shapes of marl and sandstone deposits in southern marginal parts of the county indicate low depth of sea (in Shurijeh), but the water depth increased again and the sea appears completely.

These changes coincided with the formation of the Kopet Dagh area. The marine conditions of these areas continued during the Cretaceous so that upper Cretaceous formations remained from the northern part of Kopet Dagh zone made these areas different from the rest of the country.

Sedimentation took place in the northern basin in Paleocene and Marl limestone remained in south by coming up the area, then the area with low depth appeared out of the sea surrounded by some heights in both parts of Kapet Dagh and Binalud when the sea sedimentation was over. The depth of these basins was low and the conglomerate deposits in the Southeast of Bojnoord are some typical outcrops of these sediments.

Generally, Binalud tectonic situation is specifically different from Kopet Dagh. Kopet Dagh region faced unrest tectonic in early Triassic that made folding faults and folds as a result of its activity. The process of these folding in Kopet Dagh area appeared in shape of the asymmetric anticline and syncline from North West to South East appeared.

The sedimentary layers are generally along the North West-South East, and general direction of slope is to the North and North East. General trend of the main faults are as well as folding, from North West-South East while a few faults disorganized layers order and revised the layers slope.

While Binalud section has some folds, faults and severe disorganization, all faults are thrust or big angle reverse with the east-west trend and the slope to the North. (Bojnoord geological map, scale 1: 100,000$)$

\section{Bojnoord County Climatic characteristics}

Bojnoord County is located in the mountain area and has the unique weather condition, so that these ups and downs ripples will protect the country from the cold northern wind pass through some northern cities such as Quchan, Shirvan and Faruj. On the other hand, rainfall and some Natural Springs origin from mountains lead to improving agricultural products in different parts of the county.

\section{Temperature}

The average of annual temperature in Bojnoord County is about 13.2 degrees, the average of annual maximum and minimum temperature is 19.6 degrees and $7.1^{\circ} \mathrm{C}$, respectively. August with the average of maximum temperature, about $28.3^{\circ} \mathrm{C}$, and February with average of minimum temperature, $2.8^{\circ} \mathrm{C}$, is the warmest and the coldest months of the year, respectively. The above mentioned average temperature indicates that since Bojnoord County is locating in the mountainous area, temperature is low in winter, especially in December, January and February which is usually below $5^{\circ} \mathrm{C}$.

\section{Rainfall}

Bojnoord synoptic station statistical data indicates that the annual average rainfall is about $256.8 \mathrm{~mm}$ in this county. The highest amount of rainfall per month is in March, with the 
average of $45.2 \mathrm{~mm}$, and in April, with $43.1 \mathrm{~mm}$.

It should be noted that due to cold weather conditions in Bojnoord as a semi-arid city there are some restrictions in this country such as, limited growing season in summer and also water restrictions, so it seems that paying attention to other potentials of the area for further expansion of its residents is needed. Moreover, Some phenomena such as foggy weather especially in spring and autumn is a factor to attract travellers, movie makers and photographers for visiting the stunning landscapes, magnificent mountains and its beautiful nature.

\section{Vegetation}

The main vegetation of the area is composed of steppe and sagebrush and the area is divided in to different vegetation zones according to climate conditions of Bojnoord County as follows:

1. Semi-steppe zone.

2. Thinning forests area, especially in arid areas: including areas over $1400 \mathrm{~m}$ altitude with drought tolerant species such as juniper.

3. Plateau area: Including flat area where is flatter than higher altitude with spiny plant species such as Astragalus and Rhizome.

4. The high mountains area: including Aladaq and Saluk mountains over 2,600 meters heights where is the habitat of some plant species such as juniper with short stalks to survive against severe storms. (Watershed Management, 2005)

\section{Unique Morphological Situations and Regional Opportunities}

The most beautiful syncline valleys can be seen in Zagros folded and Kopet Daq mountains. (Zomorodian, 2002)

\section{Anticline and Syncline}

The anticline and syncline created by erosion and fault emerged of the beautiful shapes and unique landscapes in this area where cannot be seen anywhere. Sedimentary erosion layers of anticline with beautiful jagged ridges present the magnificent scenery. On the other hand, Ayub village is located in the middle of an anticline with its hot springs can also be a tourist destination to attract a lot of travellers annually.

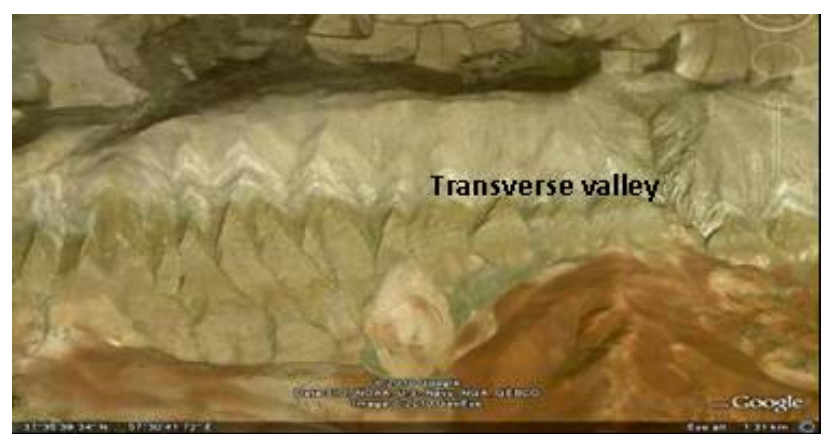

Figure 3. North West internal wall of Sheikh Syncline and forms (Source: Google earth) 


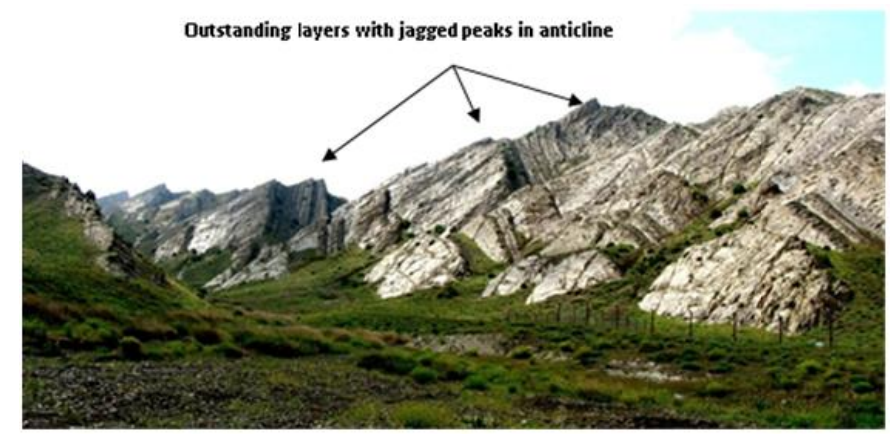

Figure 4.

Southern heights in Darband with jagged peaks (Photo by author)

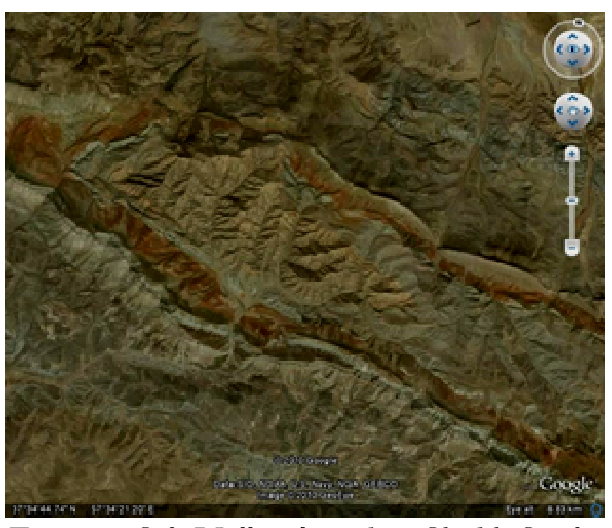

Figure 5. Sub Valleys located in Sheikh Syncline (Source: Google earth)

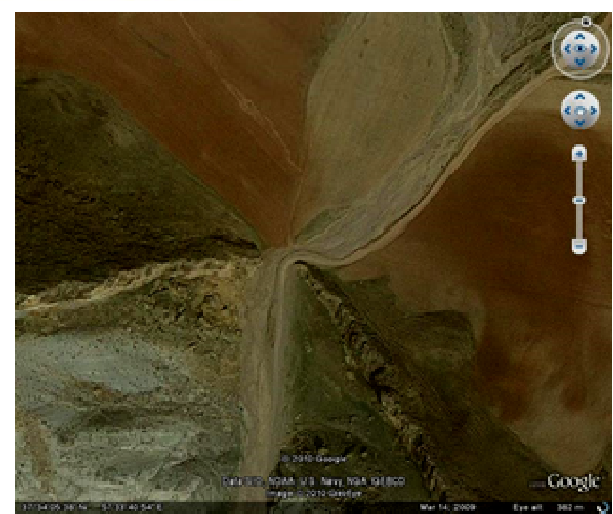

Figure 6. A close view of the Rusyaru valley (Source: Google earth)

\section{Firouzeh Dike}

There are small volcanic rocks near Firouzeh village located in $14.5 \mathrm{~km}$ of the South West of Bojnoord city that had influence on Neogene conglomerate $(\mathrm{Ngc})$ to make the pyroxene olivine basalt and basaltic andesite compositions. (Jafarian, Taheri)

Penetrating the volcanic rock into Shourijeh structure could create a discontinuity in early Pleistocene and made an island shape and a specific topography in the region because of its hardness and resistance in compare to Shourjeh. Different variety of colors in the mountains overlooking Firouzeh village make it a very picturesque village. (Jafari, 2008)

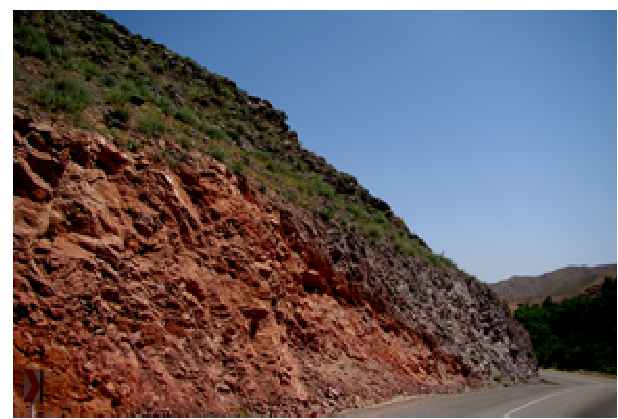

Figure 7. Dike in Firouzeh Road (Photo by author)

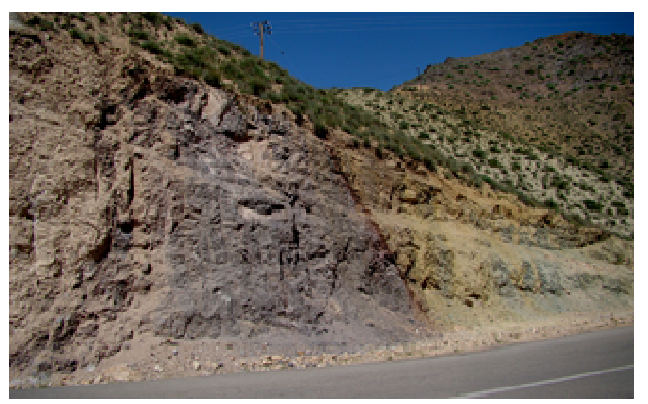

Figure 8. Dike in Firouzeh Road (Photo by author) 


\section{The Structure Without Slope (Horizontal)}

The structure will be horizontal in case changes do not occur in rock stratification and will indicate as plains, flatlands and plateaus. (Mahmoudi, 2009) The lack of significant shape in sedimentary layers is the main characteristics of this type of structure. So, plains, flatlands and plateaus even in Quaternary terrace surfaces must be classified in this category. (Zomorodian, 2002)

\section{Plateaus}

Although there is not any plateau or plateau lands in Bojnoord county due to the structural features within the country area (folds formation), some similar morphological shapes in the northern part of the county (in North and North East of Taze qale village, with longitude and latitude of $57^{\circ} 18^{\prime}$ and $38^{\circ} 4^{\prime}$, Baqleq village, with longitude and latitude of $56^{\circ} 57^{\prime}$ and $38^{\circ} 5^{\prime}$ and Qolaman city with $57^{\circ} 9^{\prime}$ and $38^{\circ} 3^{\prime}$, respectively) cause a phenomena called Mesa which is a semi-plateau in micron scale. Mesa is a high and vast plateau or single hill with a flat top in semiarid area exposed to destructions. This plateau has usually horizontal stratums with a resistant layer on top and sever slope in different sides. (Shayan, 2005)

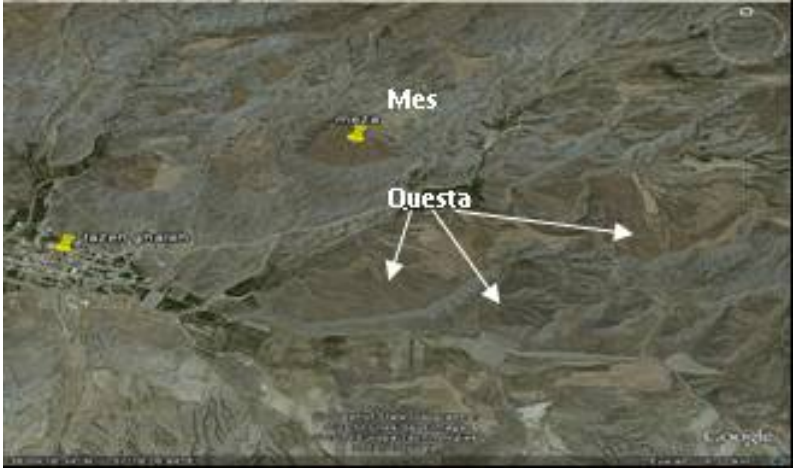

Figure 9. Satellite image of Cuestas and Mesas in East of Taze Qale

\section{Transverse Valleys}

The water transverse networks that cross along the axis of the anticlines create some deep valleys called canyons that connect two adjacent synclines (Mahmudi, 2009). Such phenomena can be visible in the northern heights of Bojnoord County called Mianzu Mountains. In fact, Ayub, with therapeutic hot springs, and Mianzu village are located among these valleys.

Ayub and Mianzu are located on

Sanganeh structures composed of gray shale and marlstone. Anticline edges are made of lime stone and these two points formed the transverse valleys of the anticline (Ayub with $37^{\circ} 53^{\prime} \mathrm{N} /$ $57^{\circ} 23^{\prime} \mathrm{E}$, and Mianzu with $\left.37^{\circ} 54^{\prime} \mathrm{N} / 57^{\circ} 19^{\prime} \mathrm{E}\right)$. The water transverse networks cross along the anticline axis and creat deep canyons that finally connect two adjacent synclines together.

\section{Weather Conditions}

Semi-arid climate and the morphology of the mountains with rocks, hills and cliffs create opportunities to attract tourists and nature lovers in all seasons. Climbing, paragliding, cave trekking, biking and hiking along the alleys are some pleasure for tourists.

\section{Erosion:}

Various perspectives, different lithology and morphology have been created by erosion factor in this area. 


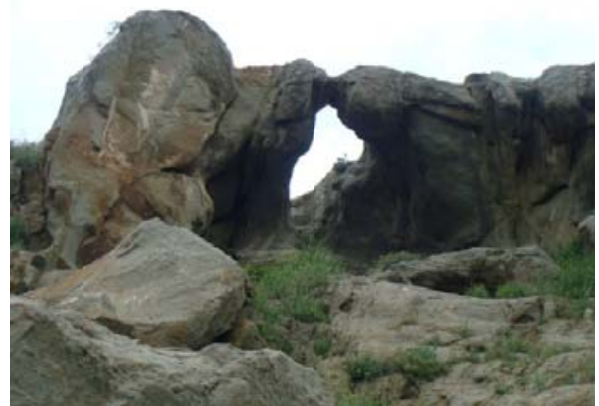

Figure 10. Small and big boles in Tirgan structure, Qazi village in Gyfan rural district

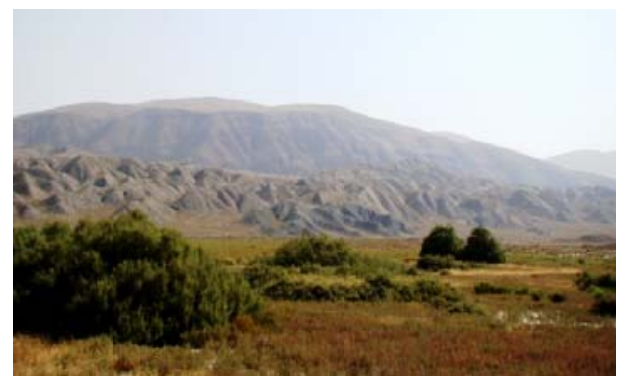

Figure 11. Hilly formation in south of Naveh village

\section{Karst Springs}

One of the most attractive geo-morphological phenomena in Bojnoord County is karst springs with its own unique characteristics, such as Baba Aman, Besh Qardash, Esfidan and Garivan:

Baba Aman spring with its beautiful and eye-catching architecture located on the main road direction of Bojnoord-Mahhad attracts many passengers and travellers annually. Moreover, Besh Qardash spring on the way to Bojnoord - Esfaraen (6 km to the south of Bojnoord) with a beautiful pool and old trees have welcomed by many passengers as well.

In the end, it should be noted that this country in terms of having some features namely, being the center of city, having the geographical and particularly political division and the minimum distance to geological attractions in compare to the other parts of the province has special different attractions to bring the possibility of visiting sites in the region.
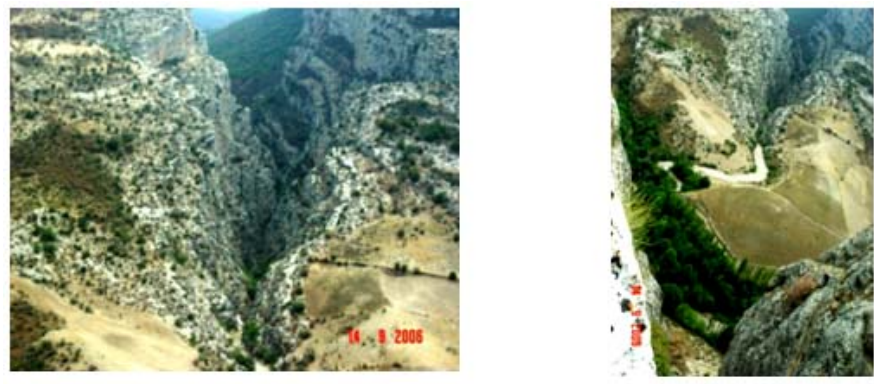

Figure 12. Canyon in Darkesh, Maneh and Samarqan villages (Photo by author)

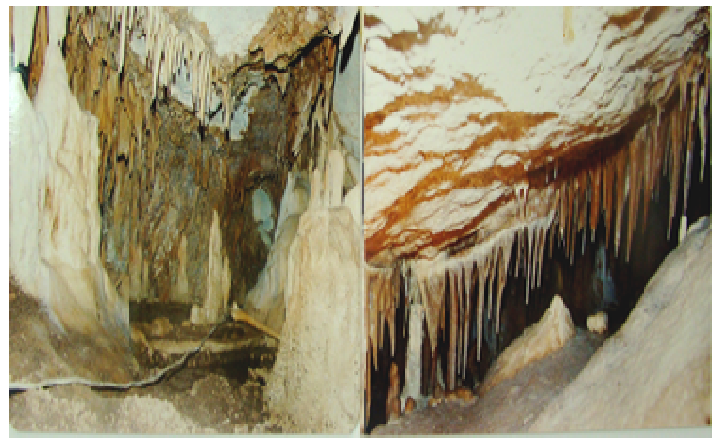

Figure 13. Volcanic Dike in Bojnoord-Esfaraen road direction (Photo by author)

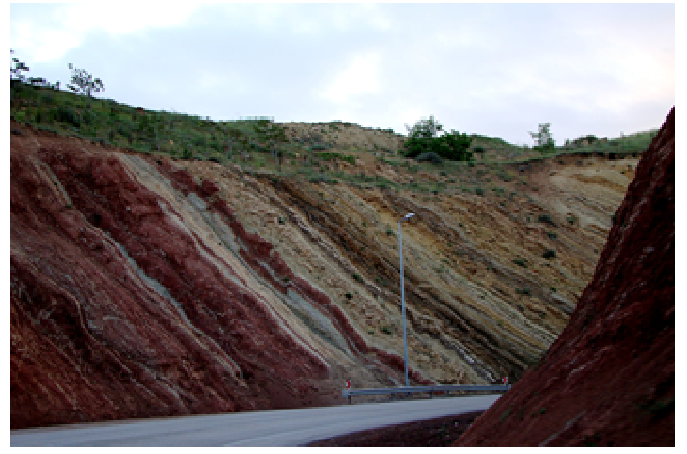

Figure 14. Volcanic Dike in Bojnoord-Esfaraen road direction (Photo by author) 


\section{Conclusion}

Despite some features of Bojnoord County such as geological attraction of anticlines and synclines, karst areas, natural springs and hot springs, waterfalls, natural juniper forests and green valleys with less distance to geological attractions of the other countries around has the proper potential in developing geo-tourism industry. On the other hand, native people and special talented forces graduated from Bojnoord University can be a strength point as human resources working on geo-tourism development plan by the aim of governmental policies.

The concept of development and definition of geo-tourism clarify that geo-tourism and ecotourism is a proper way to achieve sustainable development goals. Because their goals are generally the same as the result of several years global efforts to improve living conditions on the earth, so we should try to establish sustainable tourism in this country.

Since geo-tourism called a responsible trip and its purpose is protecting the Environment and improving local living conditions, some part of its income spends on preserving the county to improve the economy growth. Also rural and local community members are the guardian of natural resources for free.

\section{Suggestions}

Since tourism planning is a comprehensive mechanism combined of tourism development programs, transport development, economic and social development, infrastructure development and Environment development, so adding some items to tourism development plans can be effective as follows:

1. Preparing a geo-tourism map and organizing a recreational trip program.

2. Applying young professional forces to guide and manage ecotourism tours and explain natural phenomena of the country according to the sightseeing plan in order to visit magnificent natural attractions while having fun, doing sports and walking through route and areas where is impossible to access by vehicles. Group of experts and geologists accompany tourists to explain them about the beauty and strange of nature as well. Indeed, such programs have been interested in other parts of the world too.

3. Applying rural experiences people and having indigenous knowledge about surrounding environment can help visitors satisfy their curiosity about nature, so accompany a native acquainted with the county can assure travellers trip.

4. Preparing an updated tourism information database in provinces and cities by organizing "the tourist destinations center" that can give the government and relevant organizations an opportunity to record some principles of geo-tourism in order to take maximum advantages of tourist attractions.

The main strategy is helping the investors to take part in geo-tourism planning in several activities, first of all the total amount of money benefits from geo-tourism is needed to determine, Second to keep the budget, and third to develop the wealth and spend its income on tourist areas again.

Thus, this achievement could be possible with the aim of national and local tour guides in an organized team work in partnership with some agencies involved in tourism issues to guide people by preparing some related website and maps. Such an idea can improve the tourism industry and the concept of sustainable geo-tourism which has recently been introduced in this industry as a successful benchmark in other countries too.

5. Beneficial Using of some opportunities, such as applying volunteer forces in scientific researches to help general people take part in tourism plans. Amazing achievement has been achieved in some similar experiences by people cooperation.

6. Tourism infrastructure development. 


\section{Resources}

Amri Kazemi, A., (2009), Geo-park and Geo-tourism capabilities of Iran, Geological and Mineral exploration of the country, National database of Geosciences, $454 \mathrm{p}$.

Jafari, D., (2008), Feasibility of tourism in Firouzeh Bojnoord county, Cultural management, Handicrafts, Tourism and Tourism deputy.

Jafarian, Taheri, Bojnoord Geological map in scale of 1:100,000, Geological and Mineral exploration of the country, National database of Geosciences.

Wikipedia the free encyclopedia.

Dram, A., Allen, Ranjbar, M., (2009), Introduction to ecotourism management and planning, Vol. I, Ayeesh publications, $160 \mathrm{p}$.

Darvishzadeh, A., 2003, Geological of Iran, Amir Kabir Publications, 901 p.

Rahmani, A., (2008), Geo-tourism in Gonbadloran gas springs, Aftab Persian internet site, March 21, 2008. Retrieved from http://www.aftab.ir.

Zomorodian, MJ, (2001), Geomorphology of Iran construction processes and internal dynamics, 1st vol, 1st ed, Mashhad Ferdosi University publications, 281 p.

Agriculture Organization of Khorasan, Watershed management, (2005), basin management studies in Pashande Razjergolan, 5th vol, 18-34 pp.

Shayan, S., (2005), Natural geography dictionary, 6th ed, school publications, 508p.

Shayan, S., (2006), Survey the Geo-tourism obstacles and difficulties in Iran with emphasis on desert Geotourism, Geography and Sustainable Tourism National Conference, Islamic Azad University, Eslamshahr, Tehran, $134 \mathrm{p}$.

Geography dictionary of the country villages, North Khorasan province, Bojnoord city, (2005), 1st ed, the geographical organization of Ministry of Defense and support, $223 \mathrm{p}$.

Mahmoudi, F., (2009), Geomorphological structure, 3rd ed, Payam-e Noor University Press, 177 p.

Retrieved from http://www.Geo xpro.com/Geo tourism-Hiking through the Paleocene.

Retrieved from http://www. Northcoast ca.com. (CSD).

whaly. J. (2006). Egyptian secret treasure. Retrieved from http:// www.geo xpro. 